\title{
Comparison of Soybean Transformation Efficiency and Plant Factors Affecting Transformation during the Agrobacterium Infection Process
}

\author{
Yuying Jia, Xingdong Yao, Mingzhe Zhao, Qiang Zhao, Yanli Du, Cuimei Yu * and Futi Xie * \\ Soybean Research Institute, Shenyang Agricultural University, Shenyang 110866, China; \\ E-Mails: jiayuyinggood@163.com (Y.J.); yaoxingdong@gmail.com (X.Y.); \\ soyshen@163.com (M.Z.); zqiang1987@126.com (Q.Z.); dy10305@sina.cn (Y.D.) \\ * Authors to whom correspondence should be addressed; \\ E-Mails: snsoybean@sohu.com (F.X.); yucuimei@163.com (C.Y.); \\ Tel./Fax: +86-24-8848-7135 (F.X. \& C.Y.).
}

Academic Editor: Marcello Iriti

Received: 6 June 2015 / Accepted: 30 July 2015 / Published: 7 August 2015

\begin{abstract}
The susceptibility of soybean genotype to Agrobacterium infection is a key factor for the high level of genetic transformation efficiency. The objective of this study is to evaluate the plant factors related to transformation in cotyledonary nodes during the Agrobacterium infection process. This study selected three genotypes (Williams 82, Shennong 9 and Bert) with high transformation efficiency, which presented better susceptibility to Agrobacterium infection, and three low transformation efficiency genotypes (General, Liaodou 16 and Kottman), which showed a relatively weak susceptibility. Gibberellin (GA) levels and soybean GA20ox2 and CYP707A2 transcripts of high-efficiency genotypes increased and were higher than those of low-efficiency genotypes; however, the opposite performance was shown in abscisic acid (ABA). Higher zeatin riboside (ZR) content and DNA quantity, and relatively higher expression of soybean IPT5, CYCD3 and CYCA3 were obtained in high-efficiency genotypes. High-efficiency genotypes had low methyl jasmonate (MeJA) content, polyphenol oxidase (PPO) and peroxidase (POD) activity, and relatively lower expression of soybean $O P R 3, P P O 1$ and $P R X 71$. GA and ZR were positive plant factors for Agrobacterium-mediated soybean transformation by facilitating germination and growth, and increasing the number of cells in DNA synthesis cycle, respectively; MeJA, PPO, POD and ABA were negative plant factors by inducing defence reactions and repressing germination and growth, respectively.
\end{abstract}


Keywords: soybean; transformation; cotyledonary node; Agrobacterium infection; plant factors

\section{Introduction}

Over the past decade, genetically modified soybean has continued to be the predominant commercialized biotech crop, reaching 75.4 million hectares (almost 50\% of the total worldwide biotech crop area) in 2011 [1]. Transgenic technology provides an attractive alternative to conventional soybean breeding programs, especially in introducing valuable agronomic traits such as herbicide and pest resistance [2,3]. However, high-efficiency transgenic soybean methodologies still need to be developed for many elite soybean lines which are insusceptible to Agrobacterium infection [4,5].

Most plant transformation systems are lengthy processes comprised of multiple complicated steps. Agrobacterium-mediated transformation is proved to be a superior soybean transformation method over other transformation systems because it offers significant advantages including easier manipulation, lower transgene copy number and greater transgene stability, which frequently result in a higher transformation success rate [6]. To generate a stable Agrobacterium-mediated transgenic soybean line, foreign genes (contained within T-DNA) are delivered from Agrobacterium into plant host cells and eventually integrated into the host genome. This infection process is a very critical early step of the whole transformation process beginning with recognition of plant signals by Agrobacterium, followed by Agrobacterium attachment to the wounded plant tissue and the survival of imported T-DNA from the host defense system [7]. Therefore, successful Agrobacterium infection is necessary for ensuring a high level of soybean transformation efficiency, which depends on both plant genotypes [5,8] and Agrobacterium strains [9,10]. Compared with systematically studied Agrobacterium events during infection [11-13], our understanding on the host plant events has mostly focused on T-DNA and biochemical compounds. Multiple studies have identified a set of plant proteins and genes which involve T-DNA import, transport and integration into the plant genome [14-18]. On the other hand, a number of plant cell secreted compounds have been shown to affect infection through inducing or inhibiting the expression of Agrobacterium virulence genes [19-21]. Although great success has been achieved in characterization of plant factors affecting the Agrobacterium infection process, more efforts are required to investigate details on the delicate plant cellular response during Agrobacterium infection.

Since the successful transformation of the cultivated soybean by Agrobacterium-mediated method in 1988 [22], a lot of researchers discussed the conditions affecting soybean transformation to optimize the soybean transformation system [8,23-25]. Improved transformation systems enhanced the soybean transformation efficiency, but the degree of improvement was limited. Moreover, some studies showed that in soybean genotypes existed a variation in susceptibility to Agrobacterium [4], and many researchers mainly focused on screening soybean cultivars of high transformation efficiency. Soybean cultivar Williams 82 was commonly used in soybean transformation, usually as a control. Jack, Peking and Bert were also suitable cultivars in different transformation culture conditions [10,23,26,27]. Researchers also identified some Chinese cultivars with a stable transgenic efficiency $[5,25]$. 
Studies optimizing Agrobacterium-mediated transformation, the addition of phenolic compounds [28], antioxidants [29,30] and phytohormones [31,32] partly enhanced the transformation. Phenolic compounds, like acetosyringone (AS), have been found to be essential for induction of the virulence gene [20]. These antioxidant reagents (L-cysteine, thiol compounds and dithiothreitol) appeared to improve T-DNA delivery by inhibiting the activity of plant pathogen-response and wound-response enzymes, such as polyphenol oxidase (PPO) and peroxidase (POD) [33], but did not fundamentally repress plant defense reaction to Agrobacterium infection. In plant tissue culture, adding phytohormones usually caused changes in endogenous hormones. Endogenous hormones played essential roles in regulating plant growth, development, and stress responses. Gibberellin (GA) is known to induce the germination process and promote degradation of storage material in seeds [34], providing the material and energy basis for the explants. Abscisic acid (ABA) not only acted as an antagonist to GA [35,36], but also had an involvement in responses to flooding, pathogen attack and wounding [37]. Methyl jasmonate (MeJA) involved in plant development and the regulation in the expression of plant defense genes in response to various stresses such as wounding, drought, and pathogens [38]. Bacterial infection and wounding are necessary in Agrobacterium-mediated transformation systems, MeJA may participates in this process. Other phytohormones such as cytokinin were required to induce cell division and growth in plant tissue cultures. Villemont et al. [39] investigated that Petunia mesophyll cycling cells with no phytohormone treatments could not be transformed. Thus, efficient Agrobacterium transformation might occur at a particular stage of the plant cell cycle. The previous researches implied that germination and growth, cell division and defense response status of explant tissues might be a crucial effect on the transformation.

Although a lot of progress has been made in soybean transformation, transgenic efficiency still requires improvement. Most screened cultivars had a shortcoming on agronomic traits. Genotype-dependency of the soybean transformation significantly limited its application of elite and commercially valuable cultivars. It took a long time for breeding a commercial transgenic soybean after getting a transgenic plant in the laboratory. If researchers can get high transformation efficiency at any time from elite and commercially valuable cultivars, the transgenic breeding efficiency would be improved greatly. As soybean genotypes display a variation in susceptibility to Agrobacterium [4], which plant factors are involved? To the best of our knowledge, there has been no report concerning the identification and analysis of plant factors from soybean. The objective of this study is to evaluate the plant factors related to transformation in cotyledonary nodes during the Agrobacterium infection process as based on the screened soybean cultivars with contrasting transformation efficiencies. Our data suggest that GA and ZR play a positive role on Agrobacterium-mediated soybean transformation; however, ABA, MeJA, PPO and POD have a negative effect. Furthermore, these factors participated in germination and growth, cell division and defense response in cotyledonary nodes.

\section{Results}

\subsection{Transformation Efficiencies of Various Soybean Cultivars}

There was a significant transformation difference among ten given cultivars (Table 1). After selection with $5 \mathrm{mg} \cdot \mathrm{L}^{-1}$ phosphinothricin on shoot induction medium for four weeks, resistant explants 
to phosphinothricin produced multiple observable buds (Figure 1C), while non-resistant explants had no buds (Figure 1D). Williams 82 grew well and had $80.69 \%$ resistant shoot induction rate, followed by Shennong 9 and Bert, while General, Liaodou 16 and Kottman showed significantly inferior resistant shoot induction rate. Transformation efficiencies of To plants of Williams 82, Shennong 9 and Bert were $6.71 \%, 5.32 \%$ and $5.13 \%$, respectively, which were superior to other cultivars. In addition, transformation efficiencies of Dennison, Kottman, General and Liaodou 16 were very poor, below 1\%, and Liaodou 16 even did not produce a positive plant. Based on the transformation efficiency, we screened three high-efficiency genotypes including Williams 82, Shennong 9 and Bert and three low-efficiency genotypes such as General, Liaodou 16 and Kottman. These genotypes had contrasting transformation efficiencies, and thus were used in the subsequent experiments.

Table 1. Evaluation of 10 soybean cultivars for Agrobacterium-mediated transformation.

\begin{tabular}{cccccc}
\hline Cultivar & $\begin{array}{c}\text { No. of Explants } \\
\text { Infected }\end{array}$ & $\begin{array}{c}\text { No. of Explants with } \\
\text { above Three Shoots }\end{array}$ & $\begin{array}{c}\text { Resistant Shoot } \\
\text { Induction Rate (\%) }\end{array}$ & $\begin{array}{c}\text { No. of Positive } \\
\text { T }_{\mathbf{0}} \text { Plants }\end{array}$ & $\begin{array}{c}\text { Transformation Efficiency } \\
\text { of T Plants (\%) }\end{array}$ \\
\hline Liaodou16 & 348 & 11 & 3.2 & 0 & 0 \\
General & 481 & 46 & 9.6 & 1 & 0.21 \\
Kottman & 432 & 44 & 10.2 & 3 & 0.69 \\
Dennison & 348 & 67 & 19.3 & 3 & 0.86 \\
Shennong 12 & 504 & 185 & 36.7 & 8 & 1.59 \\
Liaodou 14 & 384 & 244 & 63.5 & 7 & 1.82 \\
Liaodou 10 & 576 & 382 & 66.3 & 32 & 2.26 \\
Bert & 624 & 477 & 76.4 & 30 & 5.13 \\
Shennong 9 & 564 & 436 & 77.3 & 33 & 5.32 \\
Williams 82 & 492 & 397 & 80.7 & 6.71 \\
\hline
\end{tabular}

Resistant shoot induction rate $(\%)=($ No. of explants with at least three shoots/No. of explants infected $) \times 100$;

Transformation efficiency $(\%)=\left(\right.$ No. of positive $T_{0}$ plants/No. of explants infected $) \times 100$.

\subsection{Susceptibility of Different Soybean Genotypes to Agrobacterium Infection}

To determine the susceptibility of screened soybean genotypes to Agrobacteriumin infection, this study detected transient $\beta$-glucuronidase (GUS) expression and $B A R$ gene accumulation of cotyledonary nodes during co-cultivation period. Major GUS staining tissues were around cotyledonary nodes, which were easily accessible to the Agrobacterium. According to the stained (Figure 1E) and unstained cotyledonary node (Figure 1F), transient GUS expression rates were calculated and listed in Table 2. General, Kottman and Liaodou 16 exhibited less than 40\% staining, while Williams 82, Shennong 9 and Bert showed above 70\%, indicating that high-efficiency genotypes had a higher transient GUS expression rate. As shown in Figure 2, the BAR gene detected by PCR was the sum of that in Agrobacterium and cotyledonary node cells during co-cultivation period. BAR gene was accumulated progressively after Agrobacterium infection. It is worth noting that Williams 82, Shennong 9 and Bert accumulated more $B A R$ gene than General, Liaodou 16 and Kottman, especially at 3 days after co-cultivation (DAC) and 4 DAC, suggesting that Agrobacterium was more acceptable by high-efficiency genotypes. These results indicate that high-efficiency genotypes are more susceptible to Agrobacterium infection. 

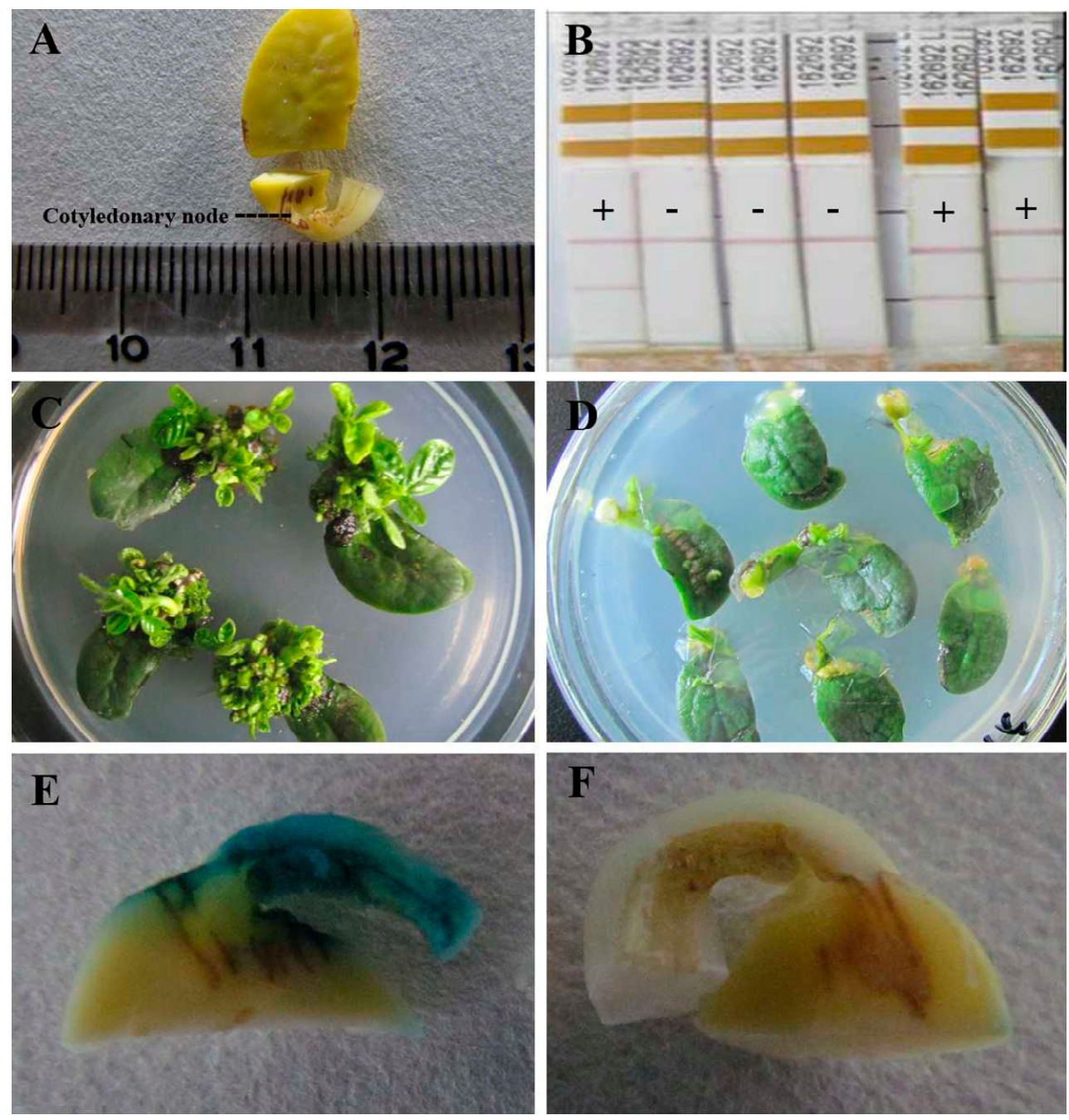

Figure 1. Cotyledonary node for determination, LibertyLink strip analysis of $\mathrm{T}_{0}$ plants, phenotype of explants after shoot induction, and GUS staining after co-cultivation for five days. (A) Sampling standard of cotyledonary node, numbers on the ruler represent centimeters; (B) Transgenic soybean plants were tested using LibertyLink strips, +: positive $\mathrm{T}_{0}$ plants, -: negative $\mathrm{T}_{0}$ plants; (C) Explants with phosphinothricin-resistant multiple buds; (D) Explants with no buds; (E) Cotyledonary node after GUS staining dyeing; and (F) Cotyledonary node with no GUS staining.

Table 2. Transient GUS expression in cotyledonary nodes from different soybean genotypes.

\begin{tabular}{cccc}
\hline Genotype & $\begin{array}{c}\text { No. of Cotyledonary Nodes } \\
\text { for GUS Staining }\end{array}$ & $\begin{array}{c}\text { No. of GUS } \\
\text { Cotyledonary Nodes }\end{array}$ & GUS $^{+}$Rate (\%) \\
\hline General & 98 & 32 & 32.7 \\
Liaodou 16 & 84 & 16 & 19.1 \\
Kottman & 100 & 30 & 30.0 \\
Williams 82 & 108 & 86 & 85.7 \\
Shennong 9 & 98 & 84 & 79.6 \\
Bert & 104 & 80 & 76.9 \\
\hline
\end{tabular}

Transient GUS expression rate $(\%)=($ No. of cotyledonary nodes with GUS staining/No. of cotyledonary nodes for GUS staining) $\times 100$. 


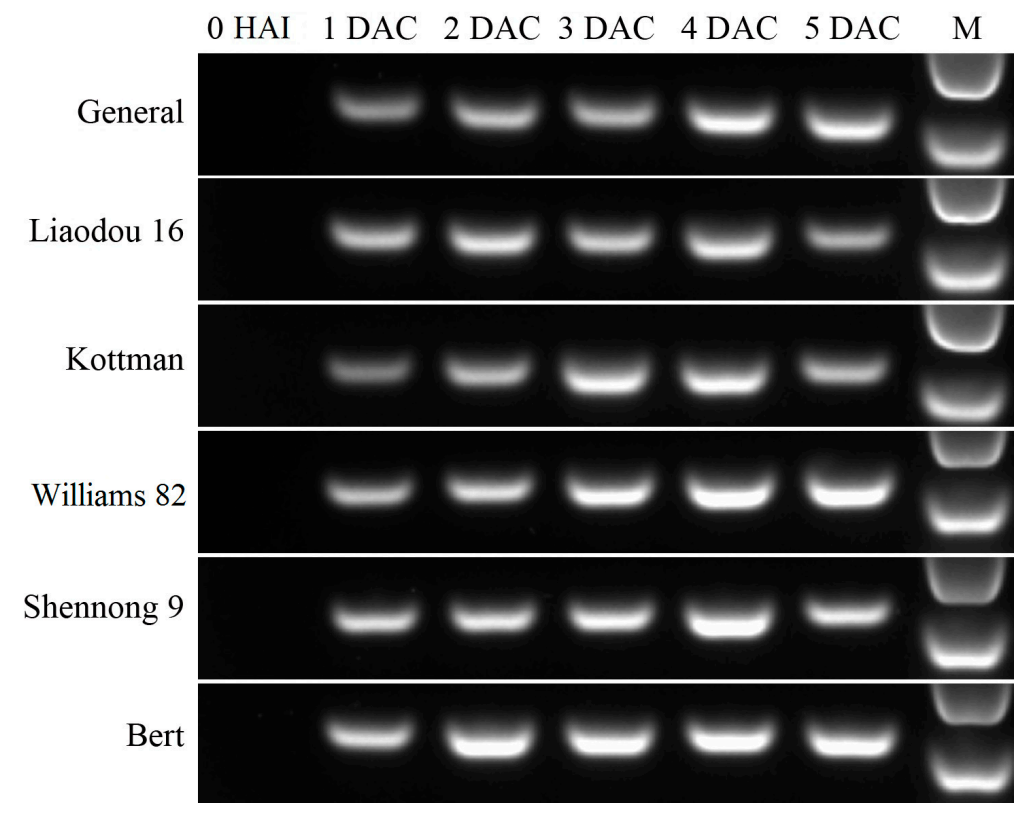

Figure 2. PCR analysis of $B A R$ gene accumulation from different genotypes during co-cultivation period. Abbreviations represent different phases: 0 HAI ( $0 \mathrm{~h}$ after infection), 1 DAC (one day after co-cultivation), 2 DAC (two days after co-cultivation), 3 DAC (three days after co-cultivation), 4 DAC (four days after co-cultivation), and 5 DAC (five days after co-cultivation). M: DL2000 marker.

\subsection{Germination and Growth Related Factors Affecting Transformation}

$\mathrm{ABA}$ acts as an antagonist to GA in regulating seed germination process $[35,36]$. Early increase in GA levels was thought to induce the germination process and promote degradation of storage material in seeds [34]. Cotyledonary node explants were also engaged in germinating and growing during co-cultivation period. In this study, prominent differences of GA and ABA levels were observed between high-efficiency genotypes and low-efficiency genotypes during the first day of co-cultivation (Table S1). GA levels increased in Williams 82, Shennong 9 and Bert, but changed slightly in General, Liaodou 16 and Kottman during the first day of co-cultivation (Figure 3A). In addition, GA content of Williams 82, Shennong 9 and Bert was markedly higher than that of General, Liaodou 16 and Kottman at 1 DAC. GA20ox2 encodes an enzyme required for biosynthesis of GA [40]. Soybean GA20ox2 transcripts increased in General, Williams 82, Shennong 9 and Bert at 1 DAC (Figure 3B), and this was roughly consistent with the changes of GA levels. In contrast with GA, ABA levels of all genotypes exhibited different degrees of decreased concentrations, where Williams 82, Shennong 9 and Bert had a lower ABA content than General, Liaodou 16 and Kottman (Figure 3C). In addition, the soybean homologue of the ABA catabolic gene CYP707A2 [41,42] exhibited a 15-fold increase in expression in Williams 82, Shennong 9 and Bert, but below a 10-fold increase in General, Liaodou 16 and Kottman at 1 DAC (Figure 3D), manifesting a more rapid decrease of ABA levels in high-efficiency genotypes, which was in agreement with ABA variation. In conclusion, high-efficiency genotypes had higher GA levels and lower ABA levels at 1 DAC, which indicated that germination and growth occured more quickly in the early stage of co-cultivation. 

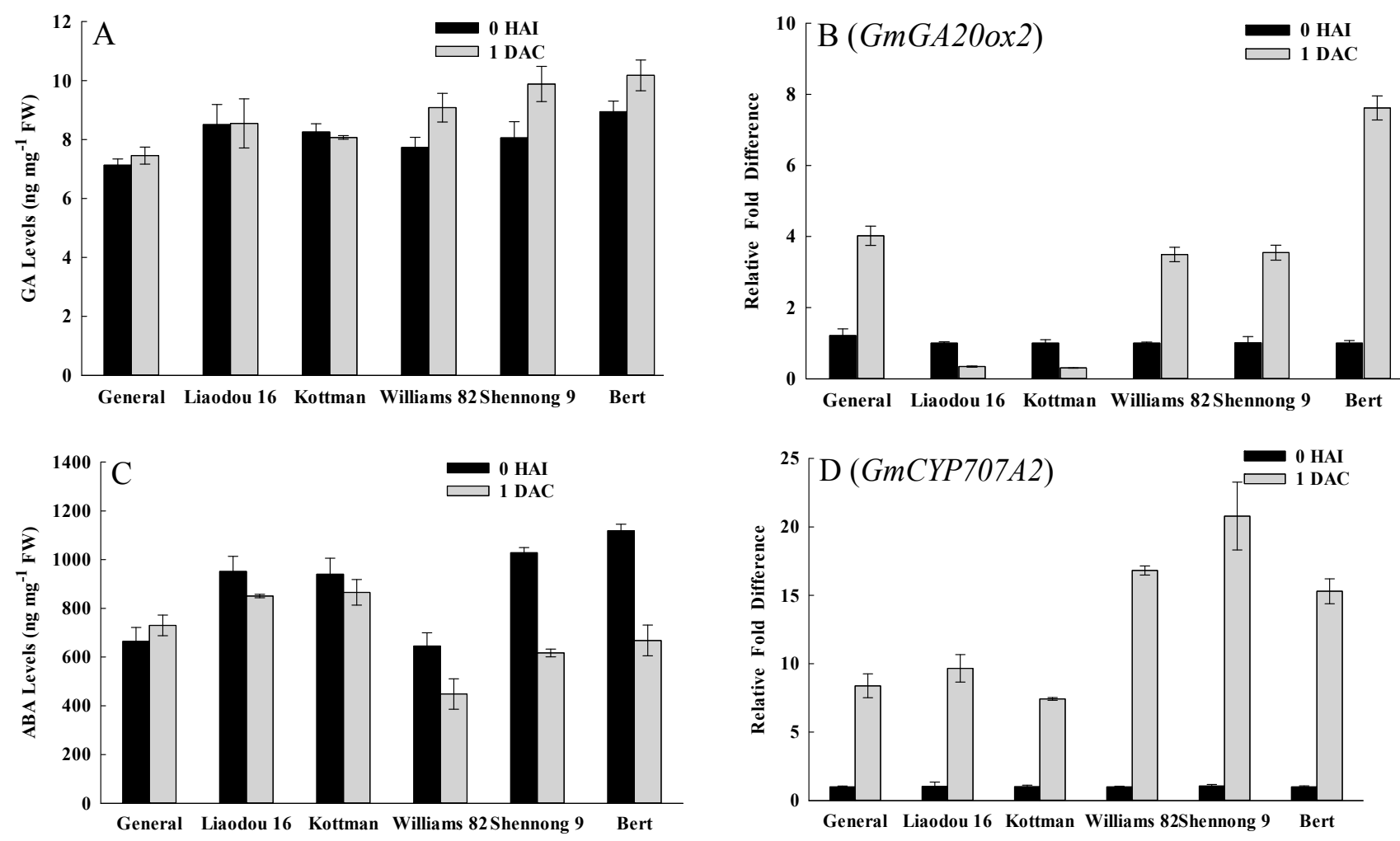

Figure 3. Comparisons of gibberellin (GA) and abscisic acid (ABA) levels, and the expression levels of genes ralated to GA and ABA metabolism between different genotypes. The values represent means \pm SD based on three biological replications. (A) GA content in cotyledonary nodes after $0 \mathrm{~h}$ of infection and after 1 day of co-cultivation; (B) qRT-PCR analysis of GA synthetic gene GmGA20ox2; (C) ABA content; and (D) qRT-PCR analysis of ABA catabolic gene GmCYP707A2.

\subsection{Cell Division Related Factors Affecting Transformation}

Cytokinins are plant hormones that regulate plant cell division. To investigate the cell division differences of genotypes during co-cultivation period, ZR levels and the transcriptional levels of IPT5 that encodes a rate limiting enzyme in cytokinin biosynthesis [43] were determined. As shown in Figure 4A, ZR concentration of Williams 82, Shennong 9 and Bert increased drastically after Agrobacterium infection, and remained at a relatively high level at 1 DAC and 3 DAC. While ZR levels in General, Liaodou 16 and Kottman increased slightly or declined. In addition, ZR content in Williams 82, Shennong 9 and Bert was significantly higher than that in General, Liaodou 16 and Kottman during the whole co-cultivation period. Expression patterns of soybean IPT5 were in accordance with ZR accumulation in all genotypes. And the relative expression of GmIPT5 in Williams 82, Shennong 9 and Bert were prominently higher than that in General, Liaodou 16 and Kottman, with a maximum at 1 DAC (Figure 4B). These results indicated that high-efficiency genotypes had higher cell division potential than low-efficiency genotypes. 

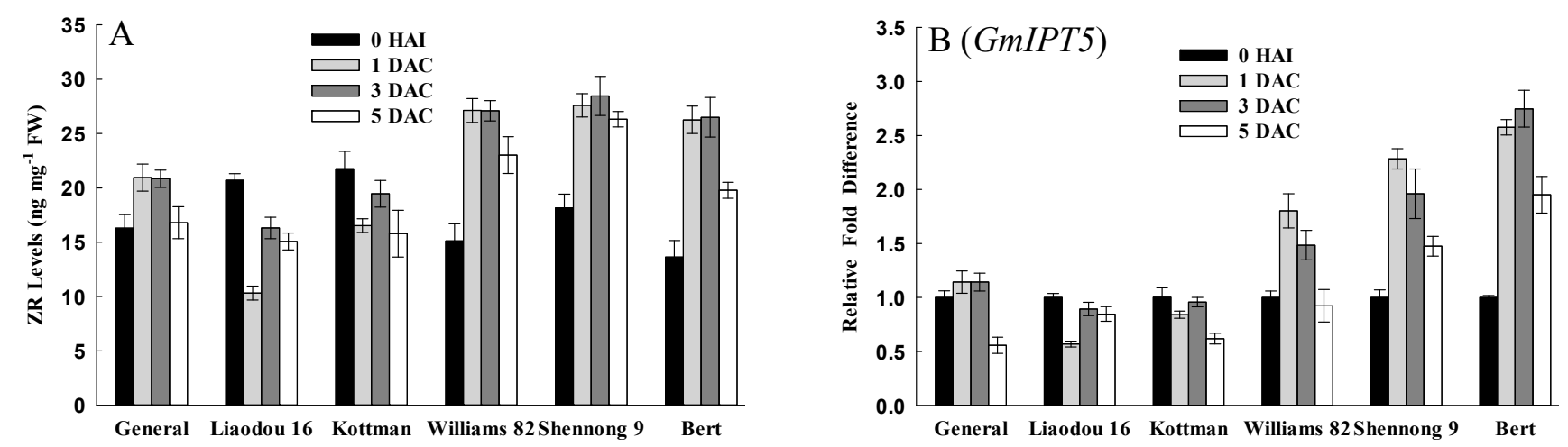

Figure 4. Comparison of zeatin riboside (ZR) levels and the expression levels of ZR synthetic gene between different genotypes. The values represent means \pm SD based on three biological replications. (A) ZR content in cotyledonary nodes after $0 \mathrm{~h}$ of infection, and after one day, three days, and five days of co-cultivation; (B) qRT-PCR analysis of ZR synthetic gene GmIPT5.

Cell division has a significant influence on Agrobacterium-mediated soybean transformation. To research the relationship between cell cycle phase and Agrobacterium transformation, this study investigated the expression of cell cycle-associated genes in different genotypes. CYCD3 is the key for stimulating G1 and G1/S transition [44]. Soybean homologue of CYCD3 was up-regulated during the co-cultivation period (Figure 5A). CYCA3 is a S-phase specific expression gene in the next DNA synthesis cycle [45]. In this study, soybean $C Y C A 3$ was up-regulated at $3 \mathrm{DAC}$ and $5 \mathrm{DAC}$ (Figure 5B). In addition, the expression of these two genes were increased more significantly in Williams 82, Shennong 9 and Bert at 3 DAC and 5 DAC, suggesting that high-efficiency genotypes had more cells entering into S-phase and being in S-phase as compared with low-efficiency genotypes in the later co-cultivation period.
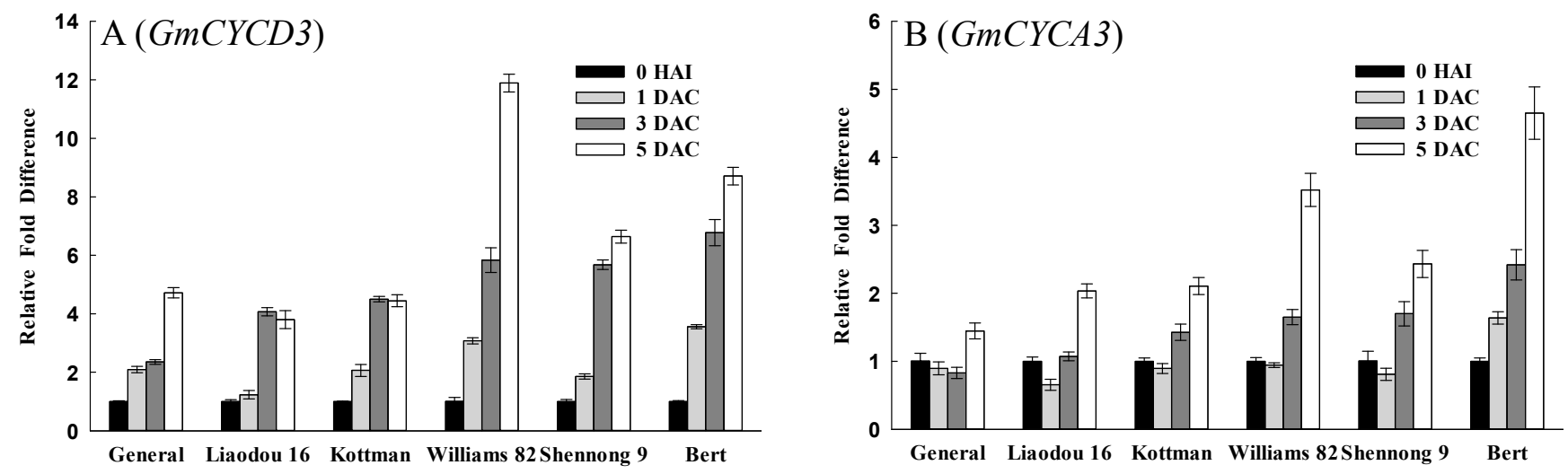

Figure 5. Comparison of the expression levels of cell cyclin-associated genes between different genotypes. The values represent means $\pm \mathrm{SD}$ based on three biological replications. (A) qRT-PCR analysis of GmCYCD3 in cotyledonary nodes after $0 \mathrm{~h}$ of infection, and after one day, three days, and five days of co-cultivation; (B) qRT-PCR analysis of $G m C Y C A 3$. 
As the S-phase is part of the DNA synthesis cycle, this led us to test the nuclear DNA quantity in meristem cells of cotyledonary nodes. Fluorescence of DAPI-stained nuclei of different genotypes is presented in Figure S1. Williams 82, Shennong 9 and Bert displayed stronger DAPI fluorescence than General, Liaodou 16 and Kottman. Average optical density (AOD) is directly proportional to DNA content, further analysis are presented in Figure 6. DNA content of Williams 82, Shennong 9 and Bert exhibited up-trend during co-cultivation period, and significantly higher than those of General, Liaodou 16 and Kottman at $3 \mathrm{DAC}$ and 5 DAC. The results indicated that soybean $C Y C A 3$ expression pattern was same as the staining pattern with DAPI, which represented replicating DNA, suggesting a tangible link between S-phase and efficient Agrobacterium transformation.

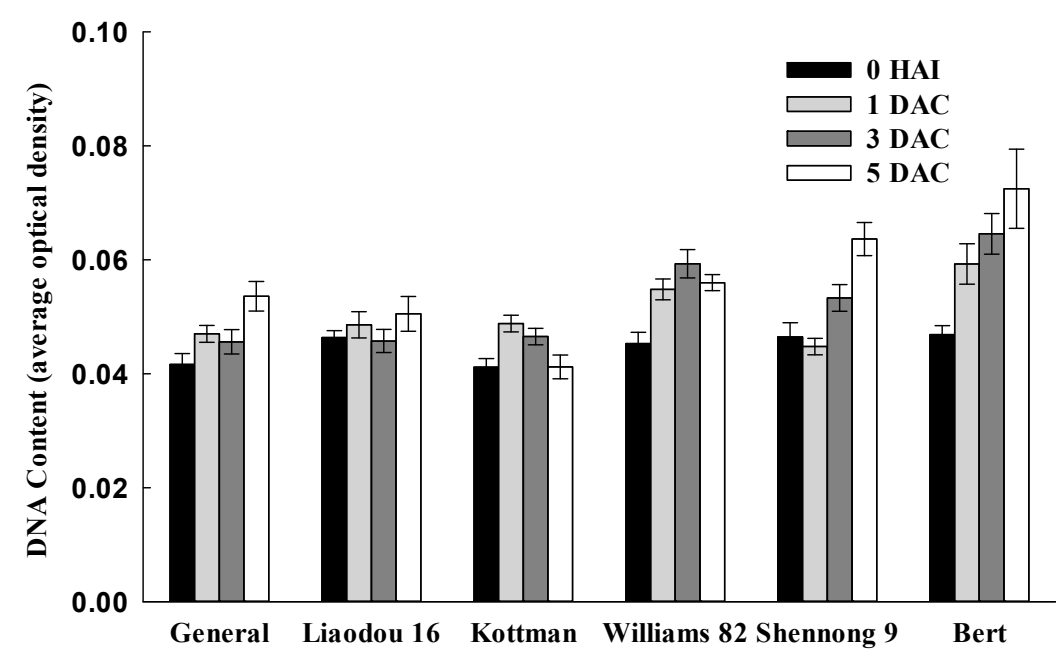

Figure 6. Comparison of nuclear DNA content in meristem cells of cotyledonary nodes between different genotypes during the co-cultivation period. The data represent the means \pm SD of all cell nucleus in the cotyledonary node.

\subsection{Defense Response Related Factors Affecting Transformation}

To study the responses of genotypes to wounding and Agrobacterium infection, MeJA levels and its synthetic gene OPR3 [46] were investigated. After wounding and Agrobacterium infection, the peak of MeJA level was observed at 1 DAC. Williams 82, Shennong 9 and Bert all increased more than 2.5-fold, but General, Liaodou 16 and Kottman only increased up to 1.5-fold (Table S1). In addition, MeJA content of Williams 82, Shennong 9 and Bert was significantly higher than those of General, Liaodou 16 and Kottman at 1 DAC (Figure 7A). A soybean homologue of OPR3 was strongly up-regulated in General, Liaodou 16 and Kottman at 1 DAC, especially increased 14-fold in General. However, the increase was less in Williams 82, Shennong 9 and Bert (below two-fold) (Figure 7B). The results indicated that wounding and Agrobacterium infection caused a significant increase in MeJA levels and GmOPR3 expression of low-efficiency genotypes.

PPO and POD are protective enzymes that respond to various stresses. In this study, PPO and POD activity and their encoding gene $P P O 1$ [47] and $P R X 71$ [48] were investigated. The results showed a striking increase of PPO and POD activity occurred during the co-cultivation period (Figure 8A,C). Moreover, PPO and POD activity in General, Liaodou 16 and Kottman was significantly higher than those in Williams 82, Shennong 9 and Bert at 3 DAC and 5 DAC. Expression of soybean homologue 
of PPO1 and PRX71 increased more significantly in General, Liaodou 16 and Kottman (Figure 8B,D), which followed a similar pattern with the variation of PPO and POD activity, respectively.
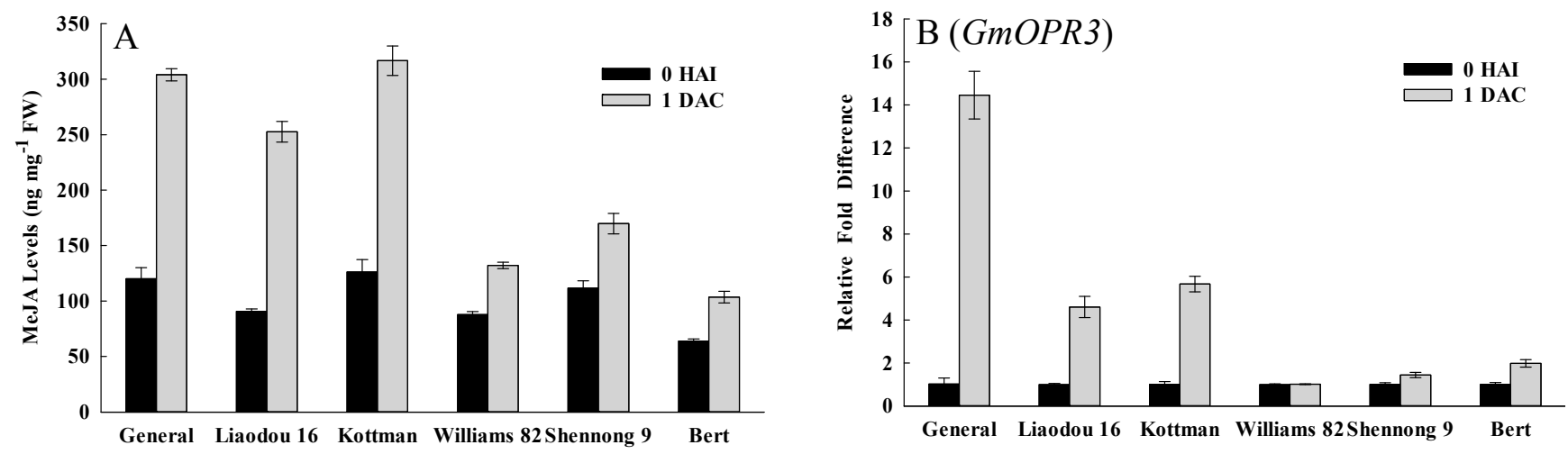

Figure 7. Comparison of methyl jasmonate (MeJA) levels and the expression levels of MeJA synthetic gene between different genotypes. The values represent means $\pm \mathrm{SD}$ based on three biological replications. (A) MeJA content in cotyledonary nodes after $0 \mathrm{~h}$ of infection and after one day of co-cultivation; (B) qRT-PCR analysis of MeJA synthetic gene GmOPR3.
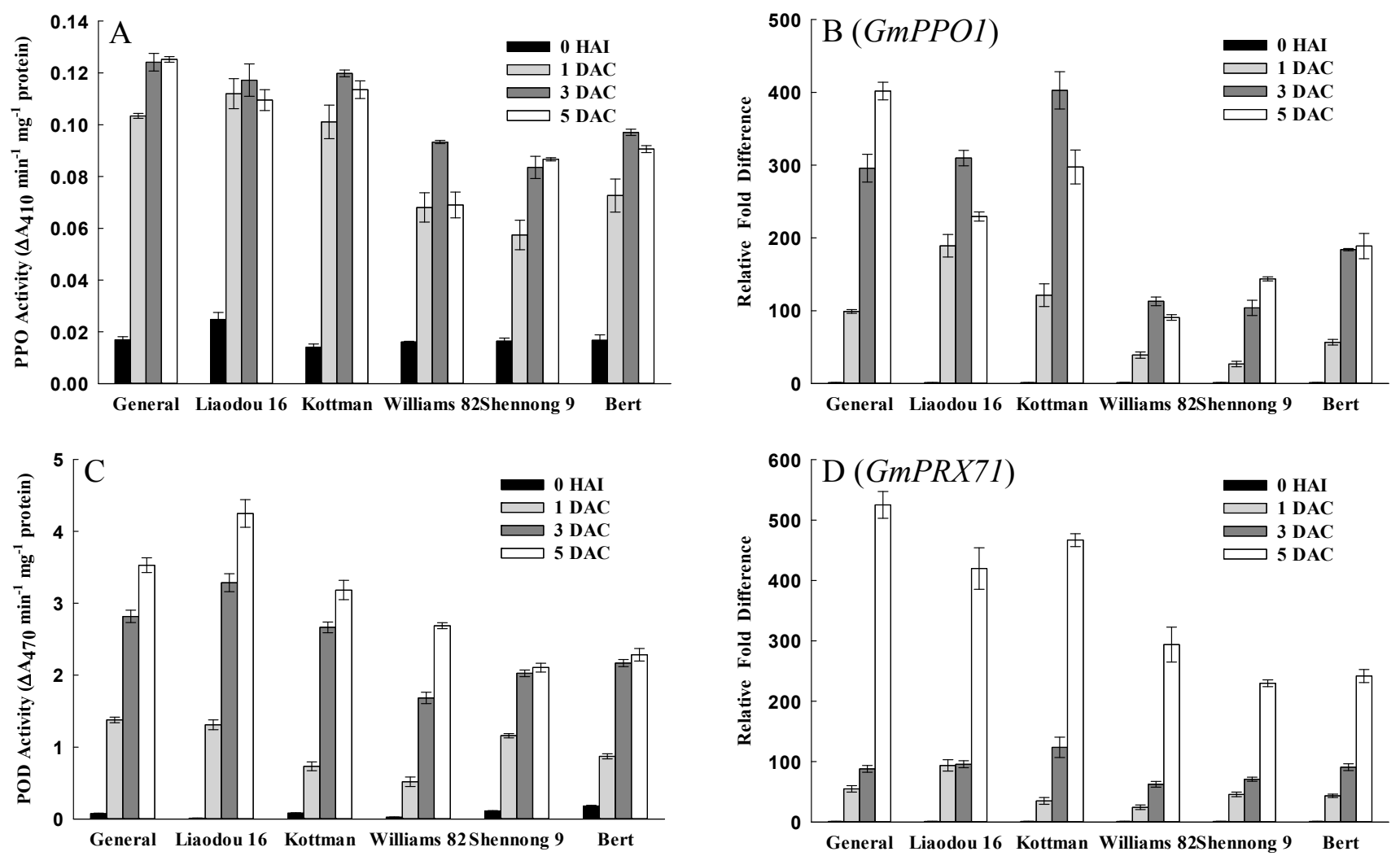

Figure 8. Comparison of polyphenol oxidase (PPO) and peroxidase (POD) activity, and the expression of encoding genes between different genotypes. The values represent means \pm SD based on three biological replications. (A) PPO activity in cotyledonary nodes after $0 \mathrm{~h}$ of infection, and after one day, three days, and five days of co-cultivation; (B) qRT-PCR analysis of the gene GmPPO1 that encodes PPO; (C) POD activity; and (D) qRT-PCR analysis of the gene GmPRX71 that encodes POD. 


\section{Discussion}

There was a significant genotype dependency in Agrobacterium-mediated soybean transformation. This study screened three high-efficiency genotypes (Williams 82, Shennong 9 and Bert) and three low-efficiency genotypes (General, Liaodou 16 and Kottman) from $\mathrm{T}_{0}$ plants (Table 1). Agrobacterium infection plays a major role in the soybean transformation processes. Boyko et al. [49] demonstrated that the increase in transformation frequency was primarily due to the increase in transgene integration efficiency rather than in tissue regeneration efficiency. In this research, we employed transient GUS expression and BAR gene accumulation to evaluate six genotypes' susceptibility to Agrobacterium infection. Soybean cultivar Williams 82 was commonly used in transformation research, which showed a relatively good performance in both transient GUS expression and BAR gene accumulation in this study, as well the genotypes Shennong 9 and Bert also performed well (Table 2 and Figure 2). Three low-efficiency genotypes presented poor transient GUS expression and $B A R$ gene accumulation. Song et al. [5] also utilized transient GUS expression and resistant shoot regeneration rate to evaluate genotypes' susceptibility to Agrobacterium infection. In our study, high-efficiency genotypes displayed higher resistant shoot regeneration rate (Table 1). These results strongly supported that high-efficiency genotypes possessed greater susceptibility to Agrobacterium infection. Increasing a genotypes' susceptibility was an important prerequisite to improve the transgenetic efficiency of recalcitrant genotypes. Therefore, this study explored some plant factors which influence Agrobacterium infection during co-cultivation period.

In our study, GA levels and soybean GA20ox2 and CYP707A2 transcripts of high-efficiency genotypes increased and were higher than that of low-efficiency genotypes at 1 DAC (Figure 3A,B,D). However, the variation of ABA showed the opposite response (Figure 3C). This implied that storage material of high-efficiency genotypes are broken down more rapidly to provide the considerable energy and nutrients needed for the growth and differentiation of the cotyledonary node. Iglesias and Babiano [50] found that mature dry seeds of chickpea contained high levels of ABA, which decreased to a very low level after germination. But our results showed that ABA content of low-efficiency genotypes reduced very little at 1 DAC (Figure 3C), may be due to a stronger response to Agrobacterium infection. This is in accordance with the result that ABA had an involvement in the responses to pathogen attack and wounding [37].

In Agrobacterium-mediated transformation systems, it is necessary to wound the cotyledonary node to release phenolic compounds and provide access to the target cell [20]. On the one hand, wounding enhances endogenous cytokinins activity to stimulate cell division [51,52]; on the other hand, wounded tissues make jasmonates (JA) or MeJA, inhibiting cell division [53,54]. Compelling results were shown in this study, on the first day after wounding and Agrobacterium infection. ZR content drastically increased in high-efficiency genotypes, but did not in low-efficiency genotypes (Figure 4A). A concurrent increase in MeJA levels was observed in low-efficiency genotypes (Figure 7A). Taken together, these data indicated that different response of genotypes to wounding resulted in the variation of different endogenous hormones, an affect on cell division. Thus, cell division was activated in high-efficiency genotypes, but may be repressed in low-efficiency genotypes. Subsequently, the expression status of soybean cell cycle-associated genes CYCD3 and CYCA3 (Figure 5) suggested that the cells, which was in S-phase or would be in S-phase, were less in low tansformation efficiency 
genotypes. The increase of MeJA levels might be correlated with cell cycle, and produce a negative impact on G1/S transition and S-phase in low-efficiency genotypes. Actually, Patil et al. [55] also discovered that MeJA elicitation can inhibit cell cycle progression by impairing G1/S transition and decreasing S-phase cells in cultured Taxus cells.

Cytokinins can activate cell division [52], and many reports have shown a direct link between cytokinins and cell cycle control. For example, the peak of zeatin $(Z)$ levels was detected at G1/S, G2/M and middle-late of S-phase in synchronized tobacco cell [56,57]. This study also showed that ZR content and expression of soybean $C Y C D 3$ and $C Y C A 3$ appeared to have a synchronous increase only in high-efficiency genotypes (Figures 4 and 5), suggesting that cell cycle had a significant influence on soybean transformation. Chateau et al. [32] suggested that efficient Agrobacterium transformation might occur at a particular stage of the plant cell cycle. Villemont et al. [39] demonstrated that Petunia mesophyll cells could not be transformed when the cell cycle was blocked in late G1 phase, and cells with the highest transformation ability were those that had a very high ratio of S $+\mathrm{G} 2$ phase/M phase. This study also showed that higher expression of soybean CYCD3 and CYCA3, and higher DNA content were obtained in high-efficiency genotypes at a later co-cultivation period (Figures 5 and 6), which implied that high-efficiency genotypes had more cells in S-phase, in which cells were being DNA replication. These findings strongly supported the notion that successful Agrobacterium-mediated transformation required DNA replication in S-phase. We speculated that DNA replication might provide a good opportunity for the insertion of exogenous genes.

Explants regard Agrobacterium as invaders in the transformation process, and produce a defense response to battle Agrobacterium infection and expression of foreign genes. In addition, wounding also induces a defense reaction, including production of protective enzymes, induction of defence-related genes and so on. In this study, after wounding and Agrobacterium infection, MeJA content of cotyledonary nodes increased rapidly especially in low-efficiency genotypes (Figure 7A). MeJA triggered defense response to induce the production of defensive proteins, protective enzymes and phenolic acids that inhibited the infection of the pathogen [58]. OPR3 can be induced by a variety of stimuli such as wounding and JA [59,60], and enhances resistance to necrotrophic fungus in Arabidopsis [61]. In this study, expression of soybean OPR3 was also increased in low-efficiency genotypes (Figure 7B), which was consistent with the observation of MeJA. The current study with higher expression of soybean $O P R 3$ and MeJA concentration in low-efficiency genotypes, taken together with previous investigations, indicate that low-efficiency genotypes possess a higher defence ability in the Agrobacterium infection process. In addition, protective enzymes, PPO and POD are involved in reactions culminating in wound-induced tissue browning and participate in defense reactions against pathogenic invasion $[62,63]$. The data here showed that PPO and POD activity, and the expression of soybean $P P O 1$ and $P R X 71$, all increased remarkably, and were significantly higher in low-efficiency genotypes (Figure 8), suggesting that there were intense defense reactions in low-efficiency genotypes. In phenol metabolism, PPO and POD could oxidate polyphenols into quinones (antimicrobial compounds), which were toxic for Agrobacterium, and typically resulted in extensive tissue browning and partial cell death to battle the infection process of Agrobacterium. These results strongly demonstrate that intense defense response of explant is a fatal weakness for Agrobacterium-mediated soybean transformation, thus efficient suppression is a prerequisite for successful transformation. 


\section{Experimental Section}

\subsection{Materials}

Ten cultivars, which had above $80 \%$ shoot regeneration rates (Table S2), were used for Agrobacterium-mediated transformation experiments, including five US cultivars General, Kottman, Dennison, Williams 82 and Bert, and five Chinese cultivars Liaodou 10, Liaodou 14, Liaodou 16, Shennong 9 and Shennong 12.

\subsection{Agrobacterium Preparation}

For our experiment, the binary plasmid, pCAMBIA3301-1 with GUS and BAR genes was introduced into the super-virulent Agrobacterium tumefaciens strain EHA105, which provided by Agro-Biotechnology Research Institute of Jilin Academy of Agricultural Sciences, China. A. tumefaciens stocks of EHA105/pCAMBIA3301-1 was grown on solidified YEP medium $\left(10 \mathrm{~g} \cdot \mathrm{L}^{-1}\right.$ peptone, $5 \mathrm{~g} \cdot \mathrm{L}^{-1}$ yeast extract, $5 \mathrm{~g} \cdot \mathrm{L}^{-1} \mathrm{NaCl}, 1.5 \%(w / v)$ agar $(\mathrm{pH} 7.0)$ ) containing $25 \mathrm{mg} \cdot \mathrm{L}^{-1}$ rifampicin and $50 \mathrm{mg} \cdot \mathrm{L}^{-1}$ kanamycin and incubated at $28{ }^{\circ} \mathrm{C}$ until colony formation. Fifty milliliters liquid YEP medium containing antibiotics (same as above but without agar) was inoculated with a single colony and shaken at $28{ }^{\circ} \mathrm{C}, 180 \mathrm{rpm}$ until the $\mathrm{OD}_{600}$ reached $0.8,-70{ }^{\circ} \mathrm{C}$ glycerol stocks. Before explant inoculation, $30 \mu \mathrm{L}$ of $A$. tumefaciens glycerol stock was added to $5 \mathrm{~mL}$ liquid YEP medium containing antibiotics for $24 \mathrm{~h}$ at $28{ }^{\circ} \mathrm{C}, 180 \mathrm{rpm}$. Subsequently, $30 \mu \mathrm{L}$ of the $5 \mathrm{~mL}$ starter culture was transferred to a $100 \mathrm{~mL}$ YEP culture, and grew overnight to $\mathrm{OD}_{600}=0.8$ at $28{ }^{\circ} \mathrm{C}$, $180 \mathrm{rpm}$. The A. tumefaciens culture was centrifuged for $10 \mathrm{~min}$ at $3500 \mathrm{rpm}$ and the pellet cell was resuspended in $1 / 10$ Gamborg's B5 medium with $3 \%(w / v)$ sucrose, $3.9 \mathrm{~g} \cdot \mathrm{L}^{-1}$ 4-Morpholineethanesulfonic acid (MES), filter-sterilized $0.25 \mathrm{mg} \cdot \mathrm{L}^{-1}$ gibberellin $\mathrm{A}_{3}\left(\mathrm{GA}_{3}\right)$, $1.67 \mathrm{mg} \cdot \mathrm{L}^{-1}$ 6-benzylaminopurine (6-BA), $400 \quad \mathrm{mg} \cdot \mathrm{L}^{-1} \quad$ L-Cysteine (L-Cys), $154.2 \mathrm{mg} \cdot \mathrm{L}^{-1}$ DL-Dithiothreitol (DL-DTT) and $200 \mu \mathrm{m} \mathrm{As,} \mathrm{pH} \mathrm{5.4.}$

\subsection{Infection and Co-Cultivation of Explant}

Soybean seeds were surface sterilized using chlorine gas made by mixing in $3.5 \mathrm{~mL}$ of $12 \mathrm{~N} \mathrm{HCl}$ and $100 \mathrm{~mL}$ bleach (5.25\% sodium hypochlorite) for $12 \mathrm{~h}$ (Figure S2A). Sterilized seeds were germinated on $\mathrm{B} 5$ medium with $2 \%(w / v)$ sucrose and $0.7 \%(w / v)$ agar, $\mathrm{pH} 5.8$, under dark for $16 \mathrm{~h}$, at $25{ }^{\circ} \mathrm{C}$ (Figure S2B). The seedling's coat was removed, and then a longitudinal cut was made to separate two cotyledonary node explants. The primary shoot was subsequently removed and the cotyledonary node was wounded by cutting 6-8 times (Figure S2C). Explants were infected with Agrobacterium suspension in the shaker (126 rpm) for $30 \mathrm{~min}$ (Figure S2D). Thereafter, ten explants were cultured per $90 \times 15 \mathrm{~mm}$ petri dish, and the explants were placed on a filter paper laid over the co-cultivation medium, same as the resuspension medium described above, solidified with $0.7 \%(w / v)$ agar. Co-cultivation plates were incubated at $24{ }^{\circ} \mathrm{C}$ for 5 days in the dark (Figure S2E). 


\subsection{Transgenetic Shoots Induction and Plant Regeneration}

After 5 days co-cultivation, the explants were briefly washed in liquid shoot induction medium containing Gamborg B5 salts, 3\% (w/v) sucrose, $0.59 \mathrm{~g} \cdot \mathrm{L}^{-1} \mathrm{MES}, \mathrm{pH} 5.7$ and filter-sterilized Gamborg B5 vitamins, $500 \mathrm{mg} \cdot \mathrm{L}^{-1}$ carbenicillin, $1.67 \mathrm{mg} \cdot \mathrm{L}^{-1} 6$-BA were added after autoclaving. Explants were subsequently removed majority of the hypocotyl approximate $3-5 \mathrm{~mm}$ below the cotyledonary node and cultured on shoot induction medium (same as above but with $0.8 \%(w / v)$ agar and $5 \mathrm{mg} \cdot \mathrm{L}^{-1}$ phosphinothricin) with the hypocotyl embedded in the medium and the cotyledonary node region facing upwards. The medium was changed every two weeks (Figure S2F). After four weeks, big shoots that may have developed from the primary shoot were cut and discarded. Explants were transferred to shoot elongation medium containing MS salts, 3\% $(w / v)$ sucrose, $0.3 \%(w / v)$ phytagel, $0.59 \mathrm{~g} \cdot \mathrm{L}^{-1}$ MES, pH 5.7 and filter-sterilized $50 \mathrm{mg} \cdot \mathrm{L}^{-1} \mathrm{~L}$-Asparagine (L-Asp), $50 \mathrm{mg} \cdot \mathrm{L}^{-1}$ L-Glutamine (L-Glu), $0.5 \mathrm{mg} \cdot \mathrm{L}^{-1} \mathrm{GA} 3,0.1 \mathrm{mg} \cdot \mathrm{L}^{-1}$ indole-3-acetic acid, $1 \mathrm{mg} \cdot \mathrm{L}^{-1}$ zeatin, $250 \mathrm{mg} \cdot \mathrm{L}^{-1}$ ticarcillin (Tic), $100 \mathrm{mg} \cdot \mathrm{L}^{-1}$ cefotaxime (Cef), and $5 \mathrm{mg} \cdot \mathrm{L}^{-1}$ phosphinothricin were added after autoclaving. The medium was changed every two weeks (Figure S2H). Culture conditions during shoot induction and elongation stages included an 18-h photoperiod at $28^{\circ} \mathrm{C}$. $2-3 \mathrm{~cm}$ long elongated shoots were placed into rooting medium comprised of MS salts, $2 \%(w / v)$ sucrose, $0.3 \%(w / v)$ phytagel, $0.59 \mathrm{~g} \cdot \mathrm{L}^{-1} \mathrm{MES}$, pH 5.6 and filter-sterilized $2 \mathrm{mg} \cdot \mathrm{L}^{-1}$ indolebutyric acid, $50 \mathrm{mg} \cdot \mathrm{L}^{-1} \mathrm{~L}-\mathrm{Asp}, 50 \mathrm{mg} \cdot \mathrm{L}^{-1} \mathrm{~L}-\mathrm{Glu}$, $250 \mathrm{mg} \cdot \mathrm{L}^{-1} \mathrm{Tic}, 100 \mathrm{mg} \cdot \mathrm{L}^{-1}$ Cef were added after autoclaving (Figure S2I). Rooted seedlings were transferred to soil grown in the greenhouse.

\subsection{Detection of $T_{0}$ Plants}

Transgenic soybean plants were verified by LibertyLink strip analysis. LibertyLink strips (Envirologix, Portland, OR, USA) were used to determinate genetically modified plants containing the phosphinothricin $N$-acetyltransferase protein following the manufacturer's instruction. Briefly, leaf tissue was ground and $0.25 \mathrm{~mL}$ of protein extraction buffer was added before regrinding. Development of the control line indicated that the strip had functioned properly, and the second line would show up when the tested sample was positive. As shown in Figure 1B, + : positive transgenic plants; -: negative transgenic plants.

\section{6. $\beta$-Glucuronidase (GUS) Staining of Cotyledonary Node}

After 5 days of co-cultivation, explants were first washed using sterile distilled water, then excised into cotyledonary node and immediately incubated with GUS histochemical stain (100 mM phosphate buffer (pH 7.0), $10 \mathrm{mM} \mathrm{Na} 2 \mathrm{EDTA}\left(\mathrm{pH} \mathrm{8.0),} \mathrm{0.8 \%} \mathrm{Triton-X,} 0.5 \mathrm{mM} \mathrm{K}_{4} \mathrm{Fe}(\mathrm{CN})_{6}, 0.5 \mathrm{mM} \mathrm{K}_{3} \mathrm{Fe}(\mathrm{CN})_{6}\right.$, $1 \mathrm{mM}$ X-gluc (Inalco, Milan, Italy)) overnight at $37{ }^{\circ} \mathrm{C}$ to verify T-DNA transfer. After staining, the explants were washed in $70 \%$ ethanol and assessed blue-staining areas.

\subsection{BAR Gene Analysis during Co-Cultivation Period}

The PCR analysis was conducted to determine $B A R$ gene accumulation during co-cultivation period. Explants were washed 5 times using sterile distilled water and surface dried with a paper towel, then excised into cotyledonary node (approximately $5 \mathrm{~mm}$ above and below junction of the cotyledon and 
the hypocotyl) (Figure 1A), immediately frozen in liquid nitrogen and stored at $-80{ }^{\circ} \mathrm{C}$. Sampling times were before infection (0 HAI), 1 day after co-cultivation (1 DAC), 2 days after co-cultivation (2 DAC), 3 days after co-cultivation (3 DAC), 4 days after co-cultivation (4 DAC) and 5 days after co-cultivation (5 DAC), respectively. Genomic DNA was extracted using DNA Extracting Kit (Takara Bio Inc., Dalian, China). The 270-bp BAR gene coding region was amplified using a pair of primers: 5'-GCACCATCGTCAACCACTA-3' and 5'-TCAGCAGGTGGGTGTAGAG-3'. The amplified products were isolated by electrophoresis on a $1 \%(w / v)$ agarose gel and photographed with the gel imaging system.

\subsection{Measurement of Gibberellin (GA), Abscisic Acid (ABA), Zeatin Riboside (ZR) and Methyl Jasmonate (MeJA) Content}

The extraction and purification of endogenous hormones used the method modified by Wang et al. [64]. Frozen samples $(1 \mathrm{~g})$ were ground in liquid nitrogen, then extracted and homogenised in $5 \mathrm{~mL}$ of cold $80 \%$ methanol (containing $40 \mathrm{mg} \cdot \mathrm{L}^{-1}$ butylated hydroxytoluene as antioxidant) in darkness period at $4{ }^{\circ} \mathrm{C}$ overnight. The extract centrifuged at $12,000 \mathrm{rpm}$ for $15 \mathrm{~min}$ at $4{ }^{\circ} \mathrm{C}$. For purification, the supernatant was passed through $\mathrm{C}_{18}$ Sep-Pak cartridges (Waters Corp., Milford, MA, USA). The eluate was dried down by pure $\mathrm{N}_{2}$ at $35{ }^{\circ} \mathrm{C}$, then dissolved in $2 \mathrm{~mL}$ of phosphate-buffered saline (PBS) (pH 7.5) containing $0.1 \%$ Tween-20 $(v / v)$ and $0.1 \%(w / v)$ gelatin. Free GA, ABA, ZR and MeJA were quantified by Enzyme-linked Immunosorbent Assay (ELISA) Kit (College of Agronomy and Biotechnology, China Agricultural University, Beijing, China) following the protocol described by Yang et al. [65]. Calculations of ELISA data were performed as described by Weiler et al. [66].

\subsection{Assay of Polyphenol Oxidase (PPO) and Peroxidase (POD) Activity}

Extract of enzymes was prepared at $4{ }^{\circ} \mathrm{C}$ using the procedure with slight modifications as suggested by Sharma and Singh [67]. Frozen samples $(0.5 \mathrm{~g})$ were ground in liquid nitrogen, together with $6 \mathrm{~mL}$ of $50 \mathrm{mM}$ phosphate buffer ( $\mathrm{pH} 7.8$ ) containing $10 \mathrm{mM}$ Polyvinylpyrrolidone (PVP) were homogenized and centrifuged at $12,000 \mathrm{rpm}$ for $30 \mathrm{~min}$ at $4{ }^{\circ} \mathrm{C}$. An ammonium sulphate fraction was carried out. Firstly, ammonium sulphate was added into extracted supernatant to give $30 \%$ saturation and centrifuged at $12,000 \mathrm{rpm}$ for $30 \mathrm{~min}$ at $4{ }^{\circ} \mathrm{C}$ to remove PVP. The supernatant was removed into a new tube, secondly the ammonium sulphate fraction precipitating between $45 \%$ and $95 \%$ saturation was collected and redissolved. Total protein concentration in soluble enzyme extracts was determined using the Bradford [68] assay. Bovine serum albumin (BSA) was used as a standard.

PPO activity was assayed by the modification of the technique described by Concellón et al. [69]. The assay medium contained $1 \mathrm{~mL}$ enzyme extract and $3 \mathrm{~mL}$ of $100 \mathrm{mM}$ catechol. The altering in absorbance at $410 \mathrm{~nm}$ was monitored at $30 \mathrm{~s}$ intervals for $3 \mathrm{~min}$ using spectrophotometer, and the average change in absorbance per min, were calculated. PPO activity was expressed as $\triangle \mathrm{A} 410 \cdot \mathrm{min}^{-1} \cdot \mathrm{mg}^{-1}$ protein.

POD was measured according to the method of Reuveni [70]. The reaction mixture (1.2 $\mathrm{mL})$ contained $0.1 \mathrm{M}$ phosphate buffer ( $\mathrm{pH} 7.0), 4 \mathrm{mM}$ guaiacol and $0.4 \mathrm{~mL}$ enzyme extract. The reaction was initiated by adding $3 \mathrm{mM} \mathrm{H} \mathrm{H}_{2}$. The increase in absorbance at $470 \mathrm{~nm}$ was measured using spectrophotometer. Levels of enzyme activity were expressed as $\Delta \mathrm{A}_{470} \cdot \mathrm{min}^{-1} \cdot \mathrm{mg}^{-1}$ protein. 


\subsection{Expression of Selected Genes}

There are three groups of selected genes used in this study. The first group of genes (GA20ox2, CYP707A2, IPT5, OPR3) encode key enzymes involved in hormone metabolism [40-43,46]. The second group of genes (PPO1, PRX71) encode PPO and POD, respectively [47,48]. The third group of genes (CYCD3, CYCA3) work in relation to cell cycle regulation [44,45]. These genes have been studied in Arabidopsis or Medicago, but have not been investigated in soybean. We obtained soybean genes that were homologous with Arabidopsis or Medicago. The information of selected genes can be found in Table S3. RNA was isolated from sampled cotyledonary nodes utilizing Plant Total RNA Isolation Kit (Qiagen, Hilden, Germany). Synthesis of cDNA was performed with a SuperScript III first-strand synthesis system (Invitrogen, Carlsbad, NM, USA) using $2 \mu \mathrm{g}$ of RNA, and $1 \mu \mathrm{L}$ of the reaction mixture was subsequently used for real-time quantitative PCR in a $50 \mu \mathrm{L}$ reaction volume using SYBR Green I (Takara Bio Inc.). Primers in Table S4 were used to amplify specific genes. EF $1 \alpha$ gene was used as a calibrator. The following thermal cycle conditions were used: $95{ }^{\circ} \mathrm{C}$ for $30 \mathrm{~s}$, followed by 35 cycles of $95{ }^{\circ} \mathrm{C}$ for $5 \mathrm{~s}, 58^{\circ} \mathrm{C}$ for $20 \mathrm{~s}$, and $72{ }^{\circ} \mathrm{C}$ for $20 \mathrm{~s}$. The qRT-PCR experiments were performed with three biological replications, and each biological replication was measured in three technical replications. Following the PCR, a melting curve analysis was performed. Threshold cycle was used for relative quantification of the input target number. Relative fold difference $(\mathrm{N})$ is the number of infected target gene transcript copies relative to the uninfected control gene transcript copies and is calculated as follows:

$$
N=2^{\Delta \Delta C \mathrm{t}}=2^{(\Delta C \mathrm{t} \text { infected }-\Delta C \mathrm{C} \text { control })}
$$

where $\Delta \Delta C_{\mathrm{t}}=\Delta C_{\mathrm{t}}$ of the infected (1 DAC, 3 DAC and 5 DAC) samples minus $\Delta C_{\mathrm{t}}$ of the uninfected control $(0 \mathrm{HAI})$ samples, and $\Delta C_{\mathrm{t}}$ is the difference in threshold cycles for the target gene and the $E F 1 \alpha$ internal reference.

\subsection{Measurement of DNA Quantity}

4'-6-Diamidino-2-phenylindole (DAPI) is utilized extensively in detecting and quantifying of DNA. Fluorescence of DAPI-stained DNA is proportional to DNA quantity. In this experiment, the cotyledonary node samples were fixed in FAA (50\% ethanol, 5\% glacial acetic acid, 10\% formalin) before embedded in Steedman's wax [71], and then cut into ribbon sections. Samples were stained for $15 \mathrm{~min}$ with $1 \mu \mathrm{g} \cdot \mathrm{mL}^{-1}$ DAPI in McIlvaine's buffer, then washed three times for 15 min each with Mcllvaine's buffer. Fluorescence microscope was used to observe the meristem of cotyledonary node, and took pictures. Fluorescent pictures were analyzed using Image $\mathrm{J}$ software (The National Institutes of Health, Madison, WI, USA), fluorescence of individual nuclei was measured to carry out DNA semiquantitative analysis. Average optical density was used as a measurement of DNA content standards, which is calculated as follows:

$$
\text { AOD (average optical density) = IOD (integrated optical density)/Area }
$$




\subsection{Statistical Analysis}

The assays of endogenous hormones, enzymes and genes were determined in three biological replications and each biological replication was measured in triplicate, the means and standard deviations were calculated. The significance analysis was performed by Duncan's new multiple-range test in DPS v7.05 statistical software (Hangzhou Reifeng Information Technology Co., Ltd., Hangzhou, China).

\section{Conclusions}

Our results indicate that soybean genotype-dependency is mainly caused by genotypes' susceptibility to Agrobacterium. There is a tangible and complex link between the plant factors that participate in the response mechanism of Agrobacterium-plant interaction. We suggest that in cotyledonary nodes GA and ZR are positive plant factors for Agrobacterium-mediated soybean transformation by facilitating germination and growth and increasing the number of cells that in DNA synthesis cycle, respectively; whereas ABA, MeJA, PPO and POD are negative plant factors for Agrobacterium-mediated soybean transformation by repressing germination and growth, and inducing defence reactions, respectively.

\section{Supplementary Materials}

Supplementary materials can be found at http://www.mdpi.com/1422-0067/16/08/18522/s1.

\section{Acknowledgments}

This work was financially supported by the Major Transgenic Project of China (2014ZX08004-004), and by the Liaoning Province Science and Technology Department (2014201007).

\section{Author Contributions}

Futi Xie, Cuimei Yu, and Mingzhe Zhao conceived and designed the experiments; Yuying Jia, Xingdong Yao, Qiang Zhao and Yanli Du performed the experiment; Yuying Jia and Xingdong Yao analyzed the data; Yuying Jia wrote the manuscript; and Futi Xie revised the manuscript.

\section{Conflicts of Interest}

The authors declare no conflict of interest.

\section{References}

1. James, C. Global status of commercialized biotech/GM crops: 2012. In The International Service for the Acquisition of Agri-Biotech Applications Brief; The International Service for the Acquisition of Agri-biotech Applications: Ithaca, NY, USA, 2012; No. 44. 
2. Miklos, J.A.; Alibhai, M.F.; Bledig, S.A.; Connor-Ward, D.C.; Gao, A.G.; Holmes, B.A.; Kolacz, K.H.; Kabuye, V.T.; MacRae, T.C.; Paradise, M.S.; et al. Characterization of soybean exhibiting high expression of a synthetic Bacillus thuringiensis cry1A transgene that confers a high degree of resistance to lepidopteran pests. Crop Sci. Soc. Am. 2007, 47, 148-157.

3. Yu, H.; Li, Y.; Li, X.; Romeis, J.; Wu, K. Expression of Cry1Ac in transgenic Bt soybean lines and their efficiency in controlling lepidopteran pests. Pest Manag. Sci. 2013, 69, 1326-1333.

4. Meurer, C.A.; Dinkins, R.D.; Collins, G.B. Factors affecting soybean cotyledonary node transformation. Plant Cell Rep. 1998, 18, 180-186.

5. Song, Z.Y.; Tian, J.L.; Fu, W.Z.; Li, L.; Lu, L.H.; Zhou, L.; Shan, Z.H.; Tang, G.X.; Shou, H.X. Screening Chinese soybean genotypes for Agrobacterium-mediated genetic transformation suitability. J. Zhejiang Univ. Sci. B 2013, 14, 289-298. (In Chinese)

6. Travella, S.; Ross, S.M.; Harden, J.; Everett, C.; Snape, J.W.; Harwood, W.A. A comparison of transgenic barley lines produced by particle bombardment and Agrobacterium-mediated techniques. Plant Cell Rep. 2005, 23, 780-789.

7. Tzfira, T.; Citovsky, V. From host recognition to T-DNA integeration: The function of bacterial and plant genes in the Agrobacterium-plant cell interaction. Mol. Plant Pathol. 2000, 1, 201-212.

8. Zia, M.; Rizvi, Z.F.; Rehman, R.U.; Chaudhary, M.F. Agrobacterium mediated transformation of soybean (Glycine max L.): Some conditions standardization. Pak. J. Bot. 2010, 42, 2269-2279.

9. Hobbs, S.L.A.; Jackson, J.A.; Mahon, J.D. Specificity of strain and genotype in the susceptibility of pea to Agrobacterium tumefaciens. Plant Cell Rep. 1989, 8, 274-277.

10. Yukawa, K.; Kaku, H.; Tanaka, H.; Koga-Ban, Y.; Fukuda, M. Enhanced soybean infection by the legume "super-virulent" Agrobacterium tumefaciens strain KAT23. Biosci. Biotechnol. Biochem. 2008, 72, 1809-1816.

11. Gelvin, S.B. Agrobacterium-mediated plant transformation: The biology behind the "gene-jockeying" tool. Microbiol. Mol. Biol. Rev. 2003, 67, 16-37.

12. Christie, P.J.; Atmakuri, K.; Krishnamoorthy, V.; Jakubowski, S.; Cascales, E. Biogenesis, architecture, and function of bacterial type IV secretion systems. Annu. Rev. Microbiol. 2005, 59, 451-485.

13. McCullen, C.A.; Binns, A.N. Agrobacterium tumefaciens and plant cell interactions and activities required for interkingdom macromolecular transfer. Annu. Rev. Cell Dev. Biol. 2006, 22, 101-127.

14. Tao, Y.; Rao, P.K.; Bhattacharjee, S.; Gelvin, S.B. Expression of plant protein phosphatase 2C interferes with nuclear import of the Agrobacterium T-complex protein VirD2. Proc. Natl. Acad. Sci. USA 2004, 101, 5164-5169.

15. Li, J.; Krichevsky, A.; Vaidya, M.; Tzfira, T.; Citovsky, V. Uncoupling of the functions of the Arabidopsis VIP1 protein in transient and stable plant genetic transformation by Agrobacterium. Proc. Natl. Acad. Sci. USA 2005, 102, 5733-5738.

16. Ditt, R.F.; Kerr, K.F.; de Figueiredo, P.; Delrow, J.; Comai, L.; Nester, E.W. The Arabidopsis thaliana transcriptome in response to Agrobacterium tumefaciens. Mol. Plant Microbe Interact. 2006, 19, 665-681.

17. Tenea, G.N.; Spantzel, J.; Lee, L.Y.; Zhu, Y.; Lin, K.; Johnson, S.J.; Gelvin, S.B. Overexpression of several Arabidopsis histone genes increases Agrobacterium-mediated transformation and transgene expression in plants. Plant Cell 2009, 21, 3350-3367. 
18. Anand, A.; Vaghchhipawala, Z.; Ryu, C.M.; Kang, L.; Wang, K.; Del-Pozo, O.; Martin, G.B.; Mysore, K.S. Identification and characterization of plant genes involved in Agrobacterium-mediated plant transformation by virus-induced gene silencing. Mol. Plant Microbe Interact. 2007, 20, $41-52$.

19. Zhang, J.; Boone, L.; Kocz, R.; Zhang, C.; Binns, A.N.; Lynn, D.G. At the maize/Agrobacterium interface: Natural factors limiting host transformation. Chem. Biol. 2000, 7, 611-621.

20. Joubert, P.; Beaupère, D.; Lelièvre, P.; Wadouachi, A.; Sangwan, R.S.; Sangwan-Norreel, B.S. Effects of phenolic compounds on Agrobacterium vir genes and gene transfer induction-A plausible molecular mechanism of phenol binding protein activation. Plant Sci. 2002, 162, 733-743.

21. Cangelosi, G.A.; Ankenbauer, R.G.; Nester, E.W. Sugars induce the Agrobacterium virulence genes through a periplasmic binding protein and a transmembrane signal protein. Proc. Natl. Acad. Sci. USA 1990, 87, 6708-6712.

22. Hinchee, M.A.W.; Cnnnor-Ward, D.V.; Newell, C.A.; McDonnell, R.E.; Sato, S.J.; Gasser, C.S.; Fischhoff, D.A.; Re, D.B.; Fraley, R.T.; Horsch, R.B. Production of transgenic soybean plants using Agrobacterium-mediated DNA transfer. Nat. Biotechnol. 1988, 6, 915-922.

23. Paz, M.M.; Shou, H.X.; Guo, Z.B.; Zhang, Z.Y.; Banerjee, A.K.; Wang, K. Assessment of conditions affecting Agrobacterium-mediated soybean transformation using the cotyledonary node explant. Euphytica 2004, 136, 167-179.

24. Dang, W.; Wei, Z.M. An optimized Agrobacterium-mediated transformation for soybean for expression of binary insect resistance genes. Plant Sci. 2007, 173, 381-389.

25. Liu, S.J.; Wei, Z.M.; Huang, J.Q. The effect of co-cultivation and selection parameters on Agrobacterium-mediated transformation of Chinese soybean varieties. Plant Cell Rep. 2008, 27, 489-498.

26. Donaldson, P.A.; Simmonds, D.H. Susceptibility to Agrobacterium tumefaciens and cotyledonary node transformation in short-season soybean. Plant Cell Rep. 2000, 19, 478-484.

27. Yah, B.; Reddy, M.S.S.; Collins, G.B. Agrobacterium tumefaciens-mediated transformation of soybean (Glycine $\max ($ L.) Merrill) using immature zygotic cotyledon explants. Plant Cell Rep. 2000, 19, 1090-1097.

28. Godwin, I.; Todd, G.; Ford-Lloyd, B.; Newbury, H.J. The effects of acetosyringone and pH on Agrobacterium-mediated transformation vary according to plant species. Plant Cell Rep. 1991, 9, 671-675.

29. Enríquez-Obregón, G.A.; Prieto-Samsónov, D.L.; Riva, G.A.; Pérez, M.; Selman-Housein, G.; Vázquez-Padrón, R.I. Agrobacterium-mediated Japonica rice transformation: A procedure assisted by an antinecrotic treatment. Plant Cell Tissue Organ 1999, 59, 1659-1681.

30. Olhoft, P.M.; Somers, D.A. L-Cysteine increases Agrobacterium-mediated T-DNA delivery into soybean cotyledonary-node cells. Plant Cell Rep. 2001, 20, 706-710.

31. Sangwan, R.S.; Bourgeois, Y.; Brown, S.; Vasseur, G.; Sangwan-Norreel, B.S. Characterization of competent cells and early events of Agrobacterium-mediated genetic transformation in Arabidopsis thaliana. Planta 1992, 188, 439-456.

32. Chateau, S.; Sangwa, R.S.; Sangwan-Norreel, B.S. Competence of Arabidopsis thaliana genotypes and mutants for Agrobacterium tumefaciens-mediated gene transfer: Role of phytohormones. J. Exp. Bot. 2000, 51, 1961-1968. 
33. Wang, G.; Xu, Y. Hypocotyl-based Agrobacterium-mediated transformation of soybean (Glycine max) and application for RNA Interference. Plant Cell Rep. 2008, 27, 1177-1184.

34. Sponsel, V. Gibberellins: Regulaters of plant height and seed germination adjustment factor. In Plant Physiology, 4th ed.; Taiz, L., Zeiger, E., Eds.; Academic Press: San Diego, CA, USA, 2006; p. 465.

35. Karssen, C.M.; Zagorski, S.; Kepczynski, J.; Groot, S.P.C. Key role for endogenous gibberellins in the control of seed germination. Ann. Bot. 1989, 63, 71-80.

36. Brits, G.J.; Cutting, J.G.M.; Brown, N.A.C.; Staden, J. Environmental and hormonal regulation of seed dormancy and germination in Cape fynbos Leucospermum R.Br. (Proteaceae) species. Plant Growth Regul. 1995, 17, 181-193.

37. Weyers, J.D.B.; Paterson, N.W. Plant hormones and the control of physiological processes. New Phytol. 2001, 152, 375-407.

38. Xue, R.G.; Zhang, B.; Xie, H.F. Overexpression of a NTRl in transgenic soybean confers tolerance to water stress. Plant Cell Tissue Organ 2007, 89, 177-183.

39. Villemont, E.; Dubois, F.; Sangwan, R.S.; Vasseur, G.; Bourgeois, Y.; Sangwan-Norreel, B.S. Role of the host cell cycle in the Agrobacterium-mediated genetic transformation of Petunia: Evidence of an S-phase control mechanism for T-DNA transfer. Planta 1997, 201, 160-172.

40. Phillips, A.L.; Ward, D.A.; Uknes. S.; Appleford, N.E.; Lange, T.; Huttly, A.K.; Grebe, J.E.; Hedden, P. Isolation and expression of three gibberellin 20-oxidase cDNA clones from Arabidopsis. Plant Physiol. 1995, 108, 1049-1057.

41. Kushiro, T.; Okamoto, M.; Nakabayashi, K.; Yamagishi, K.; Kitamura, S.; Asami, T.; Hirai, N.; Koshiba, T.; Kamiya, Y.; Nambara, E. The Arabidopsis cytochrome P450 CYP707A encodes ABA 8'-hydroxylases: Key enzymes in ABA catabolism. EMBO J. 2004, 23, 1647-1656.

42. Okamoto, M.; Kuwahara, A.; Seo, M.; Kushiro, T.; Asami, T.; Hirai, N.; Kamiya, Y.; Koshiba, T.; Nambara, E. CYP707A1 and CYP707A2, which encode abscisic acid 8'-hydroxylases, are indispensable for proper control of seed dormancy and germination in Arabidopsis. Plant Physiol. 2006, 141, 97-107.

43. Sakakibara, H. Cytokinins: Activity, biosynthesis, and translocation. Annu. Rev. Plant Biol. 2006, 57, 431-449.

44. Riou-Khamlichi, C.; Huntley, R.; Jacqmard, A.; Murray, J.A. Cytokinin activation of Arabidopsis cell division through a D-type cyclin. Science 1999, 283, 1541-1544.

45. Menges, M.; de Jager, S.M.; Gruissem, W.; Murray, J.A. Global analysis of the core cell cycle regulators of Arabidopsis identifies novel genes, reveals multiple and highly specific profiles of expression and provides a coherent model for plant cell cycle control. Plant J. 2005, 41, 546-566.

46. Schaller, A.; Stintzi, A. Enzymes in jasmonate biosynthesis-structure, function, regulation. Phytochemistry 2009, 70, 1532-1538.

47. Sullivan, M.L.; Hatfield, R.D.; Samac, D.A. Cloning of an alfalfa polyphenol oxidase gene and evaluation of its potential in preventing postharvest protein degradation. J. Sci. Food Agric. 2008, $88,1406-1414$.

48. Rouet, M.A.; Mathieu, Y.; Barbier-Brygoo, H.; Lauriere, C. Characterization of active oxygen-producing proteins in response to hypo-osmolarity in tobacco and Arabidopsis cell suspensions: Identification of a cell wall peroxidase. J. Exp. Bot. 2006, 57, 1323-1332. 
49. Boyko, A.; Matsuoka, A.; Kovalchuk, I. High frequency Agrobacterium tumefaciens-mediated plant transformation induced by ammonium nitrate. Plant Cell Rep. 2009, 28, 737-757.

50. Iglesias, R.G.; Babiano, M.J. Endogenous abscisic acid during the germination of chick-pea seeds. Physiol. Plant. 1997, 100, 500-504.

51. Crane, K.E.; Ross, C.W. Effects of wounding on cytokinin activity in cucumber cotyledons. Plant Physiol. 1986, 82, 1151-1152.

52. Haberer, G.; Kieber, J.J. Cytokinins. New insights into a classic phytohormone. Plant Physiol. 2002, 128, 354-362.

53. Wasternack, C.; Hause, B. Jasmonates and octadecanoids: Signals in plant stress responses and development. Prog. Nucleic Acid Res. Mol. Biol. 2002, 72, 165-221.

54. Zhang, Y.; Turner, J.G. Wound-induced endogenous jasmonates stunt plant growth by inhibiting mitosis. PLoS ONE 2008, 3, e3699, doi:10.1371/journal.pone.0003699.

55. Patil, R.A.; Lenka, S.K.; Normanly, J.; Walker, E.L.; Roberts, S.C. Methyl jasmonate represses growth and affects cell cycle progression in cultured Taxus cells. Plant Cell Rep. 2014, 33, 1479-1492.

56. Mader, J.C.; Hanke, D.E. Immunocytochemical study of cell cycle control by cytokinin in cultured soybean cells. J. Plant Growth Regul. 1996, 15, 95-102.

57. Murray, J.A.H.; Doonan, J.; Riou-Khamlichi, C.; Meijer, M.; Oakenfull, E.A. G1 cyclins, cytokinins and the regulation of the G1/S transition. In The Plant Cell Cycle and Its Interfaces; Francis, D., Ed.; Sheffield Academic Press: Sheffiel, UK, 2001; pp. 9-41.

58. Bosch, M.; Berger, S.; Schaller, A.; Stintzi, A. Jasmonate-dependent induction of polyphenol oxidase activity in tomato foliage is important for defense against Spodoptera exigua but not against Manduca sexta. BMC Plant Biol. 2014, 14, 257, doi:10.1186/s12870-014-0257-8.

59. Costa, C.L.; Arruda, P.; Benedetti, C.E. An Arabidopsis gene induced by wounding functionally homologous to flavoprotein oxidoreductases. Plant Mol. Biol. 2000, 44, 61-71.

60. Chotikacharoensuk, T.; Arteca, R.N.; Arteca, J.M. Use of differential display for the identification of touch-induced genes from an ethylene-insensitive Arabidopsis mutant and partial characterization of these genes. J. Plant Physiol. 2006, 163, 1305-1320.

61. Chehab, E.W.; Kim, S.; Savchenko, T.; Kliebenstein, D.; Dehesh, K.; Braam, J. Intronic T-DNA insertion renders Arabidopsis opr3 a conditional jasmonic acid-producing mutant. Plant Physiol. 2011, 156, 770-778.

62. Dixon, R.A.; Paiva, N.L. Stress-induced phenylpropanoid metabolism. Plant Cell 1995, 7, 1085-1097.

63. Laukkanen, H.; Haggman, H.; Kontunen-Soppela, S.; Hohtola, A. Tissue browning of in vitro cultures of Scots pine: Role of peroxidase and polyphenol oxidase. Physiol. Plant 1999, 106, 337-343.

64. Wang, Y.; Li, B.; Du, M.; Eneji, A.E.; Wang, B.; Duan, L.; Li, Z.H.; Tian, X. Mechanism of phytohormone invovlement in feedback regulation of cotton leaf senescence induced by potassium deficiency. J. Exp. Bot. 2012, 63, 5887-5901.

65. Yang, Y.M.; Xu, C.N.; Wang, B.M.; Jia, J.Z. Effects of plant growth regulators on secondary wall thickening of cotton fibres. Plant Growth Regul. 2001, 35, 233-237. 
66. Weiler, E.W.; Jourdan, P.S.; Conrad, W. Levels of indole-3-acetic acid in intact and decapitated coleoptiles as determined by a specific and highly sensitive solid-phase enzyme immunoassay. Planta 1981, 153, 561-571.

67. Sharma, R.R.; Singh, D. Phenolic content pattern, polyphenol oxidase and lipoxygenase activity in relation to albinism, fruit malformation and nubbins production in strawberry (Fragaria $\times$ ananassa Duch). J. Plant Biochem. Biotechonl. 2010, 19, 67-72.

68. Bradford, M.M. A rapid and sensitive method for the quantification of microgram quantities of protein utilizing the principle of protein-dye binding. Anal. Biochem. 1976, 72, 248-254.

69. Concellón, A.; Añón, M.C.; Chaves, A.R. Characterization and changes in polyphenol oxidase from eggplant fruit (Solanum melongena L.) during storage at low temperature. Food Chem. 2004, $88,17-24$.

70. Reuveni, R. Biochemical markers for disease resistance. In Molecular Methods in Plant Pathology; Singh, R.P., Singh, U.S., Eds.; CRC Press: Boca Raton, FL, USA, 1995; pp. 99-144.

71. Brown, R.C.; Lemmon, B.E. Methods in plant immunolight microscopy. Methods Cell Biol. 1995, 49, 85-107.

(C) 2015 by the authors; licensee MDPI, Basel, Switzerland. This article is an open access article distributed under the terms and conditions of the Creative Commons Attribution license (http://creativecommons.org/licenses/by/4.0/). 